UDC 331.107

\title{
THE INFLUENCE OF COMMERCIAL AWARENESS' FACTORS TO THE DEVELOPMENT OF THE ENTERPRISE
}

\author{
Zerkal A.V. \\ Classic Private University
}

DOI: https://doi.org/10.32839/2304-5809/2018-12-64-65

Commercial awareness means appreciating that all enterprises are themselves commercial enterprises, in business to make money. Even charities need to be sustainable. You need to understand how they do that and what factors might affect it in order to be fully commercially aware. Businesses can never stand still - they grow or die and their CEOs worry about competitors. The price/earning ratio is the most commonly used means of comparing enterprises' financial performance.

Keywords: commercial awareness, staff, enterprise, business, stakeholders, financial performance.

Tntroduction. Political, economic, social, tech-

nological, legal and environmental factors can all influence the business operation of an enterprise, its clients and competitors.

Understanding the basics of business means that you can appreciate how the enterprise aims to meet the needs of stakeholders (e.g. clients, suppliers, employees, creditors, managers, owners, shareholders, government, local community even the environment) by efficiently using often costly resources to produce effective goods or services that make a profit or generate a surplus. Understanding profit margins, how to obtain and use resources efficiently and the need to promote the enterprise professionally are all key to showing your commercial awareness.

Research results. The most dramatic development in an enterprise's life is when it goes public, also known as floating, listing, doing an Initial.

Public Offering (IPO) or a flotation. This is when its shares are listed on the Stock Exchange for the public to buy and trade (hence 'going public'). There are three reasons for doing this:

To allow the venture capitalists to realise their investment (this is known as their exit route) so they can reinvest in other small businesses, grow them, sell them and so on.

As a mark of maturity - to show the world that the business has arrived and is a major player. To raise more equity finance by issuing fresh shares to new shareholders.

It's a bit like a football club being promoted. Public enterprises have the letters 'PLC' after their name.

The enterprise issues a prospectus which is like a brochure, in which it tells the world about itself, its products, its history, its management, its prospects and its financial standing. You'll be pleased to hear that the prospectus must contain an 18-month cashflow forecast [1, p. 20].

The enterprise will appoint a number of advisers to help it, including a broker (a Stock Exchange member firm) to sponsor it. The sponsor plays a central role in advising the enterprise, e.g. on what it needs to do to meet the Stock Exchange's listing requirements. The broker acts as an interface between enterprise and potential investors. It markets the shares to them and puts in place any underwriting arrangements. Underwriting is a form of insurance that on the day the enterprise goes public its shares will be bought. The underwriters (banks and financial institutions) guarantee to take up any of the shares that aren't sold [1, p. 20].

If the flotation is a big success then investors may not get as many shares as they apply for, in which case it is said to be oversubscribed and share allocations are scaled back. If it is under-subscribed, the underwriters pick up the unallocated shares. Once the shares do trade, if they rise above the issue price, they are said to trade at a premium; if below the issue price, they are said to trade at a discount.

Old CEOs never die - they just pop up elsewhere. When an enterprise is taken over, it can be traumatic for the CEO: you may be sacked and your reputation suffers.

But some CEOs (chief executive officers), labeled captains of industry by the press, seem to go from one large enterprise to another getting massive golden hellos (a sum for signing on), big salaries and grants of share options (together known as the remuneration package) and huge golden parachutes (compensation for being sacked, for instance if the enterprise is taken over) plus enormous contributions to their pension funds [2, p. 221].

They are often the CEO of one major enterprise and on the boards of several others. Often they seem to be rewarded for failure, then pop up heading another big enterprise.

It's to stop these excesses that corporate governance - the relationship between the people running an enterprise (the board) and those who own it (institutional investors) - has become a big issue.

Often these sales are to the managers of the business being sold. This is called a management buy-out (MBO). The managers know the business better than anyone else so want to buy it; and by owning it they will put real effort into making it successful - and ultimately hope to sell it off, perhaps by going public in due course. But in order to buy the business they will need outside funding and this is usually provided by venture capitalists - another example of how these things all connect. So venture capital providers don't just fund start-ups; they also fund MBOs of established businesses [3, p. 101].

Not all MBOs are small. Some can be big deals that depend on a high degree of borrowing and are called LBOs (leveraged buy-out - leveraged means highly borrowed or highly geared). 
Some takeovers of public enterprises are done specifically to take those enterprises private. These deals are often funded by institutional investors. They put money into a fund and that fund is used to mount the takeover. The target is then dismembered and the components merged with other businesses and then sold off or listed. These deals are led by private equity boutiques. These are like venture capitalists but they specialise in public-to-private deals, as these types of M\&A are called. Venture capital is itself now regarded as part of private equity: upstream private equity is the act of raising the money from institutional investors; downstream private equity is the act of spending it, either on public-to-private deals or on start-ups (which is the traditional venture capital activity) [3, p. 101].

I've dealt with bids in some detail because they involve many sets of different professional advisers - so you may become involved in one. Also because your clients - if they are senior people in a public enterprise - will be constantly thinking about whether to make bids or (more worryingly) whether they may be on the receiving end of one.

Apart from buying other businesses, enterprises also sell off bits of their business that are no longer relevant to their strategy. These are called 'non-core' assets. Such sales often follow a successful acquisition when the bidder starts to integrate the target and realises that some bits of the acquired business are of no interest to it.

The bits not wanted can be sold off piecemeal in what are called asset sales. Or they can be injected into new, separate enterprises whose shares are then sold off. Doing this is called a hive-down. Payment can be in cash or shares (if the buyer is listed, in which case it is called a share-forshare exchange) and can be paid immediately on completion or postponed till a future date (called deferred) or based on the earnings of the business under new ownership (called an earn-out). If a buyer just wants some of the assets, this is called cherry picking.

Who determines whether an enterprise is taken over? Their shareholders, i.e. the institutional investors mentioned earlier - which is why big enterprises have investor relations units that liaise with shareholders. CEOs worry constantly about the share price of their enterprise: if it dips it may be vulnerable to a takeover; if it goes up unexpectedly, someone may be building a stake prior to announcing a bid; in either case the CEO is likely to be out of a job if the bid succeeds [1, p. 20].

Shareholders in an enterprise will stand by the management and won't sell out to a bidder if they feel the enterprise is going forward and expanding - i.e. if it has a strategy. Businesses never stand still. If they are not going forward, they are going backward, stagnating and, in relation to their competitors, shrinking. So all businesses must expand to survive or else risk being overtaken (and maybe taken over) by their competitors.

This is why businesses are forever changing. They take each other over, get rid of bits that are considered non-core, move into new markets, develop new products, change their names and branding, reinvent themselves - and they do this on an ongoing basis, in pursuit of strategies (much of this is 'buying and selling' from the sardine tale). In business, if you do stand still, your competitors will copy your ideas, undercut your prices, improve on your goods or services and steal your customers.

People get freaked when they see pages of tightly-clustered columns of figures in the financial pages of the press. But what these figures tell you is really quite straightforward.

First you have to realise that the financial pages cover all sorts of different markets from shares and bonds to bills (short-term bonds), commodities ('soft' ones like coffee and cocoa and 'hard' ones like gold), investment funds, foreign exchange (the relative values of different currencies) as well as interest rates.

Here we will focus on shares. Each share market has a number of indices - these represent an average of the prices of the enterprises whose shares are in the index. In the UK the most wellknown is the FTSE 100 mentioned above. You also get the FTSE 250, the FTSE 350 and the FTSE-AII Share [2, p. 230].

Typically, you may come across some or all of the following information about an enterprise's shares:

- Market price - the share's value at the market close the previous day (usually an average of all the quotes provided by the various market makers).

- Price change - yesterday's closing price compared to the day before.

- Price movements - the highest and lowest over the previous 12 months: this shows you how volatile (up and down) an enterprise's share price is.

- Market capitalisation - how much the enterprise is worth (arrived at by multiplying the number of shares in issue by the share price): this tells you how big the enterprise is.

- Gross dividend yield - the dividend divided by the share price expressed as a percentage: this tells you how much income return you are getting for your capital investment in the enterprise's shares. Investors wanting income (dividends) will go for a high yield.

- Price/earnings ratio - the $\mathrm{p} / \mathrm{e}$ ratio is the share price divided by the earnings per share (EPS) with EPS being the net profit over the enterprise's most recent trading year divided by the number of shares in issue. The $\mathrm{p} / \mathrm{e}$ ratio is used as a measure to compare how much dividend you get for the price of the share between enterprises in the same sector ( $p / e$ ratios differ between sectors). Another way of looking at it is that the resulting figure tells you how many years it will take on the basis of the current dividend stream to get back the cost of the share. The $\mathrm{p} / \mathrm{e}$ ratio is the single most commonly used way of assessing enterprise performance. Investors looking for growth (increase in share value over time) will look for high price/earnings.

- Dividend cover - the ratio of profits to dividends, i.e. the extent to which the current dividend is 'covered' by current profit: the better the cover the more cautious the enterprise is being in not paying out all of its profits to shareholders but retaining earnings to fund expansion.

All public enterprises produce annual reports for their shareholders, but anyone can get a copy just by asking the enterprise or looking at its website. UK enterprises are obliged to file their annual accounts at Enterprises House where they are 
available for public inspection. An annual report contains two types of information:

- Soft - details of the management's background together with their views of the enterprise's prospects and future market conditions;

- Hard - financial data.

The sorts of hard, financial information to look out for include:

- Gearing - the ratio of shareholders' funds (equity) to liabilities (debt); a high level of gearing is riskier because borrowings are high relative to equity, but may also indicate that the business is expanding fast by maximising the capital available to it.

- Income gearing - the ratio of interest payable on the enterprise's debt to the profits out of which that interest is paid; again, the higher the ratio the more the enterprise may be stretched to service its debt if profits fall, but it may also be a positive indication of an enterprise straining at the leash to expand as fast as possible.

- Pre-tax profit margin - this measures the profits earned per pound sterling of sales. Profit margin indicates how efficient an enterprise is, how sustainable its competitive advantage is and how resilient it is likely to be if faced with adverse market conditions.

- Return on capital employed (ROCE) - this is a key performance measure of what economists call 'economic rent' (sustainable return) and is indicative of a enterprise's efficiency in using its assets funded by its capital, and its ability to generate earnings that will provide future dividends - a reflection of its sustainable competitive advantage.

ROCE, however it is measured, connects with strategy. The point of strategy was to create sustainable competitive advantage. To couch this in economic terms, an enterprise is expected to generate returns that are consistently greater than its cost of capital (i.e. the money invested in it).

These returns are called economic rent by economists who say that a sustainable competitive advantage leads to above-normal rent. Of course, such rents will attract new entrants who drive down economic rents. This takes us back to Porter's Five Forces [4].

Since the primary role of an enterprise is to create value for its shareholders, the managers of the business apply a variety of ways that measure the return on the shareholders' funds, including:

- Total business return - which captures changes in the value of a business over a period and the cashflows generated by it during that period.
- CFROI (cashflow return on investment) which compares the cumulative cash invested in a business with the cash the business is producing, while allowing for the ageing of assets employed in the business as well as inflation.

- Free cashflow - operating cash less interest on loans, taxes and investment (this is in many respects the same as earnings).

- Discounted cashflow - which is used to evaluate possible projects by assessing how much the capital required to fund the project would generate if invested elsewhere, and then comparing that return to the project's expected return: if that return is less than the alternative, the project should not be undertaken (the reference to 'discounted' is because the future return has to be turned into today's money by subtracting the intervening return to get back to 'net present value' - but the key question is what discount to apply).

- EVA (economic value added) - a measure invented by consultants Stern Stewart which seeks to calculate the value of a business activity that is left over by subtracting the cost of executing that activity and the opportunity cost (i.e. what could have been generated by an alternative activity).

- For their part, shareholders may consider:

- Market value added - which is the difference between the current market value of an enterprise (i.e. its stock market value) and the capital contributed by shareholders. If it is positive, then the enterprise has added value; if not, it has destroyed shareholder value (true of many M\&A deals).

- Total shareholder return - which measures three cashflows associated with a share: purchase price (cash out); dividend stream (cash in); and value realised on sale (cash in) [2, p. 223].

Conclusions. The point of all of these measures is that different ones are appropriate at different times and for different purposes. Like the slipperiness of accounts all these measures have their limitations. Unless you are an accountant or management consultant, you don't need to understand these measures fully. You just need to recognise what business people are talking about when they mention them. In the workplace, you need to apply professional judgement, based on your commercial awareness. Any decisions you make or any forward planning that you do in the workplace should be based on you being aware of what is happening in the sector and wider environment.

\section{References:}

1. Kouzes, J.M. and Posner, B.Z. (2009). 'To lead, create a shared vision', Harvard Business Review, vol. 87, no. 1, January, p. 20-1.

2. Bezemer P., Nicholson, G. and Pugliese, A. (2018). The influence of board chairs on director engagement: A case-based exploration of boardroom decision-making, Corporate Governance: An International Review, 26, 3, pp. 219-234.

3. Chen, M.-J., Su, K.-H. and Tsai, W. (2007). "Competitive tension: the awareness-motivation-capability perspective", Academy of Management Journal, Vol. 50, pp. 101-18.

4. Porter, M.E. (1980). Competitive Strategy: Techniques for Analyzing Industries and Competitors, New York, NY: The Free Press. 
Зеркаль А.В.

Класичний приватний університет

\title{
ВПЛИВ ФАКТОРІВ КОМЕРЦЙНОЇ СВІДОМОСТІ НА РОЗВИТОК ПІДПРИЕМСТВА
}

\section{Анотація}

Комерційна свідомість має на увазі розуміння персоналом того, що основною метою підприємства є прибуток. I люди мають розуміти, як вони це роблять і які фрактори можуть вплинути на це, щоб бути повністю комерційно свідомими. Підприємства ніколи не можуть стояти на місці - вони ростуть або вмирають, а їх керівники турбуються про конкурентів. У бізнесі співвідношення ціна / дохід є найбільш часто використовуваним засобом порівняння фрінансових показників підприємств і розуміння персоналом своєї причетності до змін цих показників є обов'язковим для розвитку підприємства.

Ключові слова: комерційна свідомість, персонал, підприємство, бізнес, стейкхолдери, фрінансові показники.

\section{Зеркаль А.В.}

Классический приватный университет

\section{ВЛИЯНИЕ ФАКТОРОВ КОММЕРЧЕСКОЙ СОЗНАТЕЛЬНОСТИ НА РАЗВИТИЕ ПРЕДПРИЯТИЯ}

\begin{abstract}
Аннотация
Коммерческая сознательность подразумевает понимание персоналом того, что основной целью предприятия является прибыль. И сотрудники должны понимать, как они это делают и какие фракторы могут повлиять на это, чтобы быть полностью коммерчески сознательными. Предприятия никогда не могут стоять на месте - они растут или умирают, а их руководители беспокоятся о конкурентах. В бизнесе соотношение цена / доход является наиболее часто используемым средством сравнения фринансовых показателей предприятий и понимание персоналом своей сопричастности к изменениям этих показателей является обязательным для развития предприятия.

Ключевые слова: коммерческая сознательность, персонал, предприятие, бизнес, стейкхолдеры, фринансовые показатели.
\end{abstract}

